Editorial

\title{
Functional Materials Based on Metal Hydrides
}

\author{
Hai-Wen $\mathrm{Li}^{1}{ }^{1}$ (D), Min Zhu ${ }^{2}$, Craig Buckley ${ }^{3}$ and Torben R. Jensen ${ }^{4, *}$ \\ 1 Kyushu University Platform of Inter/Transdisciplinary Energy Research, International Research Center for \\ Hydrogen Energy and WPI International Institute for Carbon-Neutral Energy Research, Kyushu University, \\ Fukuoka 819-0395, Japan; li.haiwen.305@m.kyushu-u.ac.jp \\ 2 School of Materials Science and Engineering, Key Laboratory of Advanced Energy Storage Materials of \\ Guangdong Province, South China University of Technology, Guangzhou 510641, China; \\ memzhu@scut.edu.cn \\ 3 Department of Physics and Astronomy, Faculty of Science \& Engineering, Curtin University of Technology, \\ GPO Box U 1987, Perth 6845, WA, Australia; c.buckley@curtin.edu.au \\ 4 Center for Materials Crystallography, Interdisciplinary Nanoscience Center and Department of Chemistry, \\ Aarhus University, DK-8000 Aarhus C, Denmark \\ * Correspondence: trj@chem.au.dk
}

Received: 28 August 2018; Accepted: 30 August 2018; Published: 4 September 2018

\begin{abstract}
Storage of renewable energy remains a key obstacle for the implementation of a carbon free energy system. There is an urgent need to develop a variety of energy storage systems with varying performance, covering both long-term/large-scale and high gravimetric and volumetric densities for stationary and mobile applications. Novel materials with extraordinary properties have the potential to form the basis for technological paradigm shifts. Here, we present metal hydrides as a diverse class of materials with fascinating structures, compositions and properties. These materials can potentially form the basis for novel energy storage technologies as batteries and for hydrogen storage.
\end{abstract}

Our extreme and growing energy consumption, based on fossil fuels, has significantly increased the levels of carbon dioxide, which may lead to irreversible global climate change. The planet has plentiful renewable energy, e.g., sun and wind, but the fluctuations over time and geography call for a range of new ideas, and possibly novel technologies. The most difficult challenge appears to be the development of efficient and reliable storage of renewable energy [1]. Hydrogen has long been considered a potential means of energy storage; however, storage of hydrogen is also challenging [2]. Therefore, a wide range of hydrogen-containing materials with energy-related functions has been discovered over the past few decades [3,4]. The chemistry of hydrogen is diverse, and so also are the new hydrides that have been discovered, not only in terms of structure and composition, but also in terms of their properties [5,6]. This has led to a wide range of possible applications for metal hydrides that permeate beyond solid-state hydrogen storage [7-11]. A variety of new hydrides, proposed as battery materials, have been discovered [3]. Their properties can be exploited as fast ion conductors or as conversion-type electrodes with much higher potential energy capacities compared to materials currently used in commercial batteries [3,7,12]. Solar heat storage is also an area of great potential for metal hydrides, in principle offering orders of magnitude higher energy densities than existing materials [3,13-15].

This Special Issue of Inorganics, entitled "Functional Materials Based on Metal Hydrides", is dedicated to the wide range of emerging energy-related inorganic hydrogen-containing materials. We have collected thirteen publications, which clearly document that metal hydrides are a diverse class of materials with a range of properties, here denoted as "multi-functional materials". We hope you will enjoy the breadth of science presented in this open-access Special Issue that highlights the many different potential applications of metal hydrides. 
An excellent overview of hydride composition and properties is provided by C. Pistidda and co-workers, which also includes important historical landmarks for this class of materials from the past century [16]. In this review, a detailed account of selected aspects of the most relevant complex hydrides is reported. Owing to their high gravimetric hydrogen capacity, tetrahydroborates are extremely appealing for hydrogen storage. However, these materials have some limitations for their use for practical applications, as highlighted in [16], and as also discussed in several research papers in this special issue. The energy density of the reported materials in this special issue are compared in Table 1, which exhibit great potential of hydrides for high capacity energy storage.

Table 1. Comparison of volumetric and gravimetric energy density in various materials.

\begin{tabular}{|c|c|c|c|c|c|}
\hline Materials & $\begin{array}{l}\text { Available } \\
\text { Gravimetric } \\
\text { Hydrogen } \\
\text { Density } \\
\text { (wt \%) }\end{array}$ & $\begin{array}{l}\text { Available } \\
\text { Volumetric } \\
\text { Hydrogen } \\
\text { Density } \\
\text { (g/L) }\end{array}$ & $\begin{array}{l}\text { Gravimetric } \\
\text { Energy Density } \\
(\mathbf{k W h} / \mathrm{kg}) *\end{array}$ & $\begin{array}{l}\text { Volumetric } \\
\text { Energy Density } \\
(\mathbf{k W h} / \mathrm{L}) *\end{array}$ & Ref. \\
\hline Gaseous $\mathrm{H}_{2}(70 \mathrm{MPa})$ & 5.7 & 40 & 39 & 1.6 & [1] \\
\hline $2 \mathrm{LiBH}_{4}-\mathrm{MgH}_{2}$ & 11.8 & 96 & 5.5 & 3.1 & [5] \\
\hline $\mathrm{NaBH}_{4}$ & 10.8 & 112 & 4.2 & 4.3 & [19] \\
\hline $3 \mathrm{LiBH}_{4}-\mathrm{Er}\left(\mathrm{BH}_{4}\right)_{3}-3 \mathrm{LiH}$ & 9.0 & 147 & 3.5 & 2.3 & [20] \\
\hline $\mathrm{LiBH}_{4}-\mathrm{Mg}_{2} \mathrm{FeH}_{6}$ & 6.0 & 151 & 2.3 & 4.1 & [21] \\
\hline $\mathrm{MgH}_{2}$ & 7.6 & 110 & 3.0 & 4.4 & {$[22,23]$} \\
\hline $\mathrm{LiAlH}_{4}$ & 7.9 & 73 & 3.1 & 2.9 & [24] \\
\hline
\end{tabular}

* The energy density was calculated based on $140.4 \mathrm{MJ} / \mathrm{kg} \mathrm{H}_{2}$ at standard condition; ${ }^{* *}$ The energy density was calculated only based on the weight of active materials of electrodes without consideration of the total weight of cell.

An interesting research paper by Chong, Autrey and Jensen investigate one of the most promising hydrogen storage materials, magnesium borohydride, $\mathrm{Mg}\left(\mathrm{BH}_{4}\right)_{2}$, with a high gravimetric hydrogen density of $14.7 \mathrm{wt} \% \mathrm{H}_{2}$ [28]. Their recent research reveals that tetrahydofuran complexes of magnesium borohydride are significantly more prone to release and uptake of hydrogen under more moderate conditions. Hydrogen is released at $T<200{ }^{\circ} \mathrm{C}$ via the intermediate $\mathrm{Mg}\left(\mathrm{B}_{10} \mathrm{H}_{10}\right)$. These studies reveal new methods to optimize the hydrogen release and uptake reaction through modification of ligand coordination to magnesium [28].

The properties of complex hydrides, such as lithium borohydride, $\mathrm{LiBH}_{4}$, can also be improved creating a reactive hydride composite (RHC) [16] using aluminium, i.e., $\mathrm{LiBH}_{4}-\mathrm{Al}$ [29]. Here, Carrillo-Bucio, Tena-García and Suárez-Alcántara investigate the dehydrogenation reactions of the mechanochemically treated $2 \mathrm{LiBH}_{4}-\mathrm{Al}$ composite; also with additives, $\mathrm{TiF}_{3}$ or $\mathrm{CeO}_{2}$ [17]. A reduction in the dehydrogenation temperature and an increase in the reaction kinetics compared to $\mathrm{LiBH}_{4}$ is observed. The dehydrogenation reactions were observed to take place in two main steps, with onsets at $100{ }^{\circ} \mathrm{C}$ and $200-300{ }^{\circ} \mathrm{C}$, with a maximum release of $9.3 \mathrm{wt} \% \mathrm{H}_{2}$ for $2 \mathrm{LiBH}_{4}-\mathrm{Al} / \mathrm{TiF}_{3}$ [17]. However, aluminium-based complex hydrides were the first complex hydrides to be successfully catalysed. Nakagawa, Isobe, Ohki and Hashimoto recently investigated new types of additive effects of ball milled lithium alanate with hexagonal boron nitride, $\mathrm{LiAlH}_{4}-h$-BN [18]. The role of $h$-BN on the desorption process of $\mathrm{LiAlH}_{4}$ was discussed in comparison with the desorption properties of $\mathrm{LiAlH}_{4}-X(X=$ graphite, $\mathrm{LiCl}$ or LiI) [18].

The paper by Ouyang, Zhong, Li and Zhu, discuss the use of another additive, namely water, to promote hydrogen production from $\mathrm{NaBH}_{4}$ by hydrolysis [19]. The reaction of $\mathrm{NaBH}_{4}$ and water readily produces hydrogen, but also a stable oxide, $\mathrm{NaBO}_{2}$, as a by-product. The paper discusses the possible regeneration mechanisms of $\mathrm{NaBO}_{2}$ using magnesium [19]. 
Michael Heere and co-workers present an interesting paper concerning hydrogen release and uptake of a new type of reactive hydride composite based on a rare earth metal borohydride, erbium borohydride, $\mathrm{Er}\left(\mathrm{BH}_{4}\right)_{3}$, combined with $\mathrm{LiBH}_{4}$ and/or $\mathrm{LiH}, 3 \mathrm{LiBH}_{4}-\mathrm{Er}\left(\mathrm{BH}_{4}\right)_{3}-3 \mathrm{LiH}$ with a capacity of $9 \mathrm{wt} \% \mathrm{H}_{2}$ [20]. Sieverts-type measurements reveal a three-step desorption-absorption cycle with release of 4.2, 3.7 and $3.5 \mathrm{wt} \% \mathrm{H}_{2}$ for the first, second and third cycle. This work adds a new example to the growing interest in utilisation of rare earth metals and their unique properties [30,31].

Chaudhary, Dornheim, Orimo and co-workers investigated a transition metal containing a reactive hydride composite $(1-x) \mathrm{LiBH}_{4}-x \mathrm{Mg}_{2} \mathrm{FeH}_{6}$, and measured excellent pressure-composition-isothermal (PCT) data [21]. The results indicate that the same stoichiometric reaction $(x=0.5)$ occurred in all investigated samples with optimal hydrogen storage and reversibility properties. This is much lower than those required for the partial rehydrogenation of $\mathrm{LiBH}_{4}$. Moreover, the $x=0.5$ composite could be reversibly hydrogenated for more than four cycles without degradation of the $\mathrm{H}_{2}$ capacity. The authors conclude that magnesium hydride plays a vital role as an intermediate in the hydrogen release and uptake reactions [21].

Magnesium hydride remains highly relevant as a hydrogen storage material, and has been investigated in great detail previously [32,33]. Priscilla Huen, Mark Paskevicius, Dorthe B. Ravnsbæk and co-workers investigated the direct synthesis of nano-particulate $\mathrm{MgH}_{2}$ in a nanoporous carbon scaffold [22]. A solvent-based approach using dibutyl magnesium, $\mathrm{MgBu}_{2}$, infiltrated into four different carbon aerogels with different porosities is investigated. Three independent infiltrations of $\mathrm{MgBu}_{2}$, each with three individual hydrogenations, are conducted for each scaffold. Systematic experimental work shows that butane is release over many cycles, inferring that the dibutyl magnesium precursor is not completely reduced. The large difference in molar volume of $\mathrm{MgH}_{2}$ and $\mathrm{MgBu}_{2}$ is highlighted as a drawback for this approach [22].

Nano-particles are known to have different properties as compared to the bulk state, and this can also be used to improve metal hydride properties, including hydrogen storage [34]. Lei Wang and Kondo-Francois Aguey-Zinsou report on a novel approach to produce nanoscale $\mathrm{LiAlH}_{4} \mathrm{via}$ a bottom-up synthesis [24]. Upon further coating of these nanoparticles with Ti, the composite nanomaterial was found to decompose at $120{ }^{\circ} \mathrm{C}$ in one single and extremely sharp exothermic event with instant hydrogen release. This finding implies a significant thermodynamic alteration of the hydrogen properties of $\mathrm{LiAlH}_{4}$ induced by the synergetic effects of the Ti catalytic coating and nanosizing effects [24].

Nicola Patelli, Marco Calizzi, and Luca Pasquini analysed the effect of the interfacial free energy on the thermodynamics of hydrogen sorption in nano-scaled materials [23]. When the enthalpy and entropy terms are the same for all interfaces, as in an isotropic bi-phasic system, a compensation temperature is obtained, which does not depend on the system size nor on the relative phase abundance. They also consider the possible effect of elastic strains on the stability of the hydride phase and on hysteresis. They compare a simple model with experimental data obtained on two different systems: (1) bi-phasic nanocomposites where ultrafine $\mathrm{TiH}_{2}$ crystallite are dispersed within a $\mathrm{Mg}$ nanoparticle and (2) Mg nanodots encapsulated by different phases [23].

Most frequently, nano-materials for hydrogen storage are produced by mechano-chemistry [35]. However, Sleiman and Huot [25] investigated the effect of arc melting $\mathrm{Ti}_{1} \mathrm{~V}_{0.9} \mathrm{Cr}_{1.1}$ with zirconium additives on the microstructure and hydrogen storage properties of main BCC alloy and secondary Laves phase alloys C15 and C14. Small amounts of Zr produced fast kinetics and high hydrogen storage capacity [25].

Metal hydrides have been receiving increasing interest as battery materials, both as electrodes and ion conductors [3,5,12]. This is clearly demonstrated by Yang, Wang, Ouyang, Liu and Zhu [26] who prepared $\mathrm{MgH}_{2}$-based composites with expanded graphite (EG) and $\mathrm{TiO}_{2}$ by a plasma-assisted milling process as composite electrodes. A stable discharge capacity of $305.5 \mathrm{mAh} / \mathrm{g}$ could be achieved after 100 cycles for the $20 \mathrm{~h}$-milled $\mathrm{MgH}_{2}-\mathrm{TiO}_{2}-\mathrm{EG}-20 \mathrm{~h}$ composite electrode and the reversibility of the conversion reaction of $\mathrm{MgH}_{2}$ could be greatly enhanced. This improvement in cyclic performance 
is attributed mainly to the composite microstructure by the specific plasma-assisted milling process, and the additives $\mathrm{TiO}_{2}$ and graphite that could effectively ease the volume change during the de-/lithiation process, as well as inhibit the particle agglomeration [26].

Weeks, Tinkey, Ward, Lascola, Zidan, and Teprovich [27] analyse and compare the physical and electrochemical properties of an all solid-state cell utilizing $\mathrm{LiBH}_{4}$ as the electrolyte and aluminium as the active anode material. An initial capacity of $895 \mathrm{mAh} / \mathrm{g}$ was observed and is close to the theoretical capacity of aluminium due to the formation of a $\operatorname{LiAl}(1: 1)$ alloy. This work is the first example of reversible lithiation of aluminium in a solid-state cell and further emphasizes the robust nature of the $\mathrm{LiBH}_{4}$ electrolyte. This demonstrates the possibility of utilising other high-capacity anode materials with a $\mathrm{LiBH}_{4}$-based solid electrolyte in all-solid-state batteries [27].

We hope you will enjoy the breadth of science offered in this open-access Special Issue of Inorganics, now organised as a book. Many current frontier research challenges are discussed in the included articles. We hope this unique collection of science can create inspiration for the design and synthesis of other novel "energy-materials". This research field emphatically contributes towards a cleaner and carbon-free future.

\section{References}

1. Møller, K.T.; Jensen, T.R.; Akiba, E.; Li, H.-W. Hydrogen-A sustainable energy carrier. Prog. Nat. Sci. Mater. 2017, 27, 34-40. [CrossRef]

2. Ley, M.; Jepsen, L.; Lee, Y.-S.; Cho, Y.; Colbe, J.; Dornheim, M.; Rokni, M.; Jensen, J.; Sloth, M.; Filinchuk, Y.; et al. Complex hydrides for hydrogen storage-New perspectives. Mater. Today 2014, 17, 122-128. [CrossRef]

3. Møller, K.T.; Sheppard, D.; Ravnsbæk, D.; Buckley, C.; Akiba, E.; Li, H.-W.; Jensen, T.R. Complex metal hydrides for hydrogen, thermal and electrochemical energy storage. Energies 2017, 10, 1645. [CrossRef]

4. Yu, X.; Tang, Z.; Sun, D.; Ouyang, L.; Zhu, M. Recent advances and remaining challenges of nanostructured materials for hydrogen storage applications. Prog. Mater. Sci. 2017, 88, 1-48. [CrossRef]

5. Paskevicius, M.; Jepsen, L.; Schouwink, P.; Ĉerný, R.; Ravnsbæk, D.; Filinchuk, Y.; Dornheim, M.; Besenbacher, F.; Jensen, T.R. Metal Borohydrides and derivatives-Synthesis, structure and properties. Chem. Soc. Rev. 2017, 46, 1565-1634. [CrossRef] [PubMed]

6. Jepsen, L.; Ley, M.; Lee, Y.; Cho, Y.; Dornheim, M.; Jensen, J.; Filinchuk, Y.; Jørgensen, J.; Besenbacher, F.; Jensen, T.R. Boron-nitrogen based hydrides and reactive composites for hydrogen storage. Mater. Today 2014, 17, 129-135. [CrossRef]

7. Paskevicius, M.; Hansen, B.; Jørgensen, M.; Richter, B.; Jensen, T.R. Multifunctionality of silver closo-boranes. Nat. Commun. 2017, 8, 15136. [CrossRef] [PubMed]

8. Payandeh GharibDoust, S.; Dorthe, B.; Černý, R.; Jensen, T.R. Synthesis, structure and properties of bimetallic sodium rare earth (RE) borohydrides, $\mathrm{NaRE}\left(\mathrm{BH}_{4}\right)_{4}, \mathrm{RE}=\mathrm{Ce}, \mathrm{Pr}$, Er or Gd. Dalton Trans. 2017, 46, 13421-13431. [CrossRef] [PubMed]

9. Schouwink, P.; Ley, M.; Tissot, A.; Hagemann, H.; Jensen, T.R.; Smrčok, L.; Černý, R. Structure and properties of complex hydride perovskite material. Nat. Commun. 2014, 5, 5706. [CrossRef] [PubMed]

10. Paskevicius, M.; Ley, M.; Sheppard, D.; Jensen, T.R.; Buckley, C. Eutectic melting in metal borohydrides. Phys. Chem. Chem. Phys. 2013, 15, 19774-19789. [CrossRef] [PubMed]

11. He, L.; Li, H.-W.; Nakajima, H.; Tumanov, N.; Filinchuk, Y.; Hwang, S.-J.; Sharma, M.; Hagemann, H.; Akiba, E. Synthesis of a bimetallic dodecaborate $\mathrm{LiNaB}_{12} \mathrm{H}_{12}$ with outstanding superionic conductivity. Chem. Mater. 2015, 27, 5483-5486. [CrossRef]

12. Hansen, B.; Paskevicius, M.; Li, H.-W.; Akiba, E.; Jensen, T.R. Metal boranes: Progress and applications. Coord. Chem. Rev. 2016, 323, 60-70. [CrossRef]

13. Harries, D.; Paskevicius, M.; Sheppard, D.A.; Price, T.; Buckley, C.E. Concentrating solar thermal heat storage using metal hydrides. Proc. IEEE 2012, 100, 539-549. [CrossRef]

14. Sheppard, D.A.; Paskevicius, M.; Humphries, T.D.; Felderhoff, M.; Capurso, G.; Bellosta von Colbe, J.; Dornheim, M.; Klassen, T.; Ward, P.A.; Teprovich, J.A., Jr.; et al. Metal hydrides for concentrating solar-thermal power energy storage. Appl. Phys. A 2016, 122, 1-15. [CrossRef] 
15. Javadian, P.; Sheppard, D.; Jensen, T.R.; Buckley, C. Destabilization of lithium hydride and the thermodynamic assessment of the Li-Al-H system for solar thermal energy storage. RSC Adv. 2016, 6, 94927-94933. [CrossRef]

16. Puszkiel, J.; Garroni, S.; Milanese, C.; Gennari, F.; Klassen, T.; Dornheim, M.; Pistidda, C. Tetra- hydroborates: Development and potential as hydrogen storage medium. Inorganics 2017, 5, 74. [CrossRef]

17. Carrillo-Bucio, J.; Tena-García, J.; Suárez-Alcántara, K. Dehydrogenation of surface-oxidized mixtures of $2 \mathrm{LiBH}_{4}+\mathrm{Al} /$ Additives $\left(\mathrm{TiF}_{3}\right.$ or $\left.\mathrm{CeO}_{2}\right)$. Inorganics 2017, 5, 82. [CrossRef]

18. Nakagawa, Y.; Isobe, S.; Ohki, T.; Hashimoto, N. Unique hydrogen desorption properties of $\mathrm{LiAlH}_{4} / h-\mathrm{BN}$ composites. Inorganics 2017, 5, 71. [CrossRef]

19. Ouyang, L.; Zhong, H.; Li, H.-W.; Zhu, M. A recycling hydrogen supply system of $\mathrm{NaBH}_{4}$ based on a facile regeneration process: A review. Inorganics 2018, 6, 10. [CrossRef]

20. Heere, M.; GharibDoust, S.; Brighi, M.; Frommen, C.; Sørby, M.; Černý, R.; Jensen, T.; Hauback, B. Hydrogen sorption in erbium borohydride composite mixtures with $\mathrm{LiBH}_{4}$ and / or LiH. Inorganics 2017, 5, 31. [CrossRef]

21. Li, G.; Matsuo, M.; Takagi, S.; Chaudhary, A.-L.; Sato, T.; Dornheim, M.; Orimo, S. Thermodynamic properties and reversible hydrogenation of $\mathrm{LiBH}_{4}-\mathrm{Mg}_{2} \mathrm{FeH}_{6}$ composite materials. Inorganics 2017, 5, 81. [CrossRef]

22. Huen, P.; Paskevicius, M.; Richter, B.; Ravnsbæk, D.; Jensen, T.R. Hydrogen storage stability of nanoconfined $\mathrm{MgH}_{2}$ upon cycling. Inorganics 2017, 5, 57. [CrossRef]

23. Patelli, N.; Calizzi, M.; Pasquini, L. Interface enthalpy-entropy competition in nanoscale metal hydrides. Inorganics 2018, 6, 13. [CrossRef]

24. Wang, L.; Aguey-Zinsou, K.-F. Synthesis of $\mathrm{LiAlH}_{4}$ nanoparticles leading to a single hydrogen release step upon Ti coating. Inorganics 2017, 5, 38. [CrossRef]

25. Sleiman, S.; Huot, J. Microstructure and hydrogen storage properties of $\operatorname{Ti}_{1} \mathrm{~V}_{0.9} \mathrm{Cr}_{1.1}$ alloy with addition of $x$ wt $\% \operatorname{Zr}(x=0,2,4,8$, and 12). Inorganics 2017, 5, 86. [CrossRef]

26. Yang, S.; Wang, H.; Ouyang, L.; Liu, J.; Zhu, M. Improvement in the electrochemical lithium storage performance of $\mathrm{MgH}_{2}$. Inorganics 2018, 6, 2. [CrossRef]

27. Weeks, J.A.; Tinkey, S.C.; Ward, P.A.; Lascola, R.; Zidan, R.; Teprovich, J.A. Investigation of the reversible lithiation of an oxide free aluminum anode by a $\mathrm{LiBH}_{4}$ solid state electrolyte. Inorganics 2017, 5, 83. [CrossRef]

28. Chong, M.; Autrey, T.; Jensen, C. Lewis base complexes of magnesium borohydride: Enhanced kinetics and product selectivity upon hydrogen release. Inorganics 2017, 5, 89. [CrossRef]

29. Hansen, B.; Ravnsbæk, D.; Reed, D.; Book, D.; Gundlach, C.; Skibsted, J.; Jensen, T. Hydrogen storage capacity loss in a $\mathrm{LiBH}_{4}-\mathrm{Al}$ composite. J. Phys. Chem. C 2013, 117, 7423-7432. [CrossRef]

30. Frommen, C.; Sørby, M.; Heere, M.; Humphries, T.; Olsen, J.; Hauback, B. Rare earth borohydrides-crystal structures and thermal properties. Energies 2017, 10, 2115. [CrossRef]

31. Mansell, S.; Liddle, S. Rare earth and actinide complexes. Inorganics 2016, 4, 31. [CrossRef]

32. Crivello, J.-C.; Denys, R.V.; Dornheim, M.; Felderhoff, M.; Grant, D.M.; Huot, J.; Jensen, T.R.; Jongh, P.; Latroche, M.; Walker, G.S.; et al. Mg-based compounds for hydrogen and energy storage. Appl. Phys. A 2016, 122, 85. [CrossRef]

33. Crivello, J.-C.; Dam, B.; Denys, R.V.; Dornheim, M.; Grant, D.M.; Huot, J.; Jensen, T.R.; Jongh, P.; Latroche, M.; Milanese, C.; et al. Review of magnesium hydride based materials: Development and optimisation. Appl. Phys. A 2016, 122, 97. [CrossRef]

34. Nielsen, T.; Besenbacher, F.; Jensen, T. Nanoconfined hydrides for energy storage. Nanoscale 2011, 3, 2086-2098. [CrossRef] [PubMed]

35. Huot, J.; Ravnsbæk, D.B.; Zhang, J.; Cuevas, F.; Latroche, M.; Jensen, T.R. Mechanochemical synthesis of hydrogen storage materials. Prog. Mater. Sci. 2013, 58, 30-75. [CrossRef]

(C) 2018 by the authors. Licensee MDPI, Basel, Switzerland. This article is an open access article distributed under the terms and conditions of the Creative Commons Attribution (CC BY) license (http:/ / creativecommons.org/licenses/by/4.0/). 